UNIVERSITY
OF DEBRECEN

FACULTY OF

HeAlth

NYíREGYHÁZA

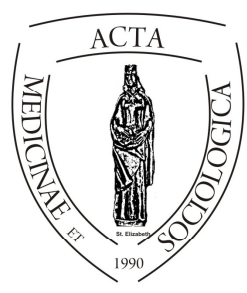

ACTA

MedSoc

VOLUME 8.

2017

\title{
RECENZIÓ
}

\section{Ártatlan Áldozatok Szatmári Svábok a Gulágon ${ }^{1}$}

\author{
Virág Ádám
}

\author{
Debreceni Egyetem Egészségügyi Kar
}

DOI: $10.19055 /$ ams.2017.8/25/10

A kötet a partiumi svábok szovjet munkatáborokba való deportálását elemzi, és az 1944-1953 között eltelt idős zak szörnyüségeit tárja az olvasók elé. A kötet jelentőségét az adja, hogy az elkészített elemzésben a szerzők a deportálás - korábbi hasonló írásokban nem részletezett - aspektusait járják körül. A könyv keletkezéséhez hozzátartozik az a tény, hogy a kiadónak személyes érintettsége van a témában oly módon, hogy családja körében is volt olyan személy, akit Oroszországba deportáltak. A személyes indíttatás a kötet egészét átitatja, így az olvasót még közelebb hozza azokhoz a borzalmakhoz, amelyet a szerkesztö részletesen bemutat. Nem utolsó sorban a mü egyben a deportálásokat átélők, és azok családtagjaik elötti tisztelet kifejezését is célozza.

\footnotetext{
${ }^{1}$ Szerzők: Boros Ernő, Baumgartner Bernadette, Fényi József, Ludescher Gabriella: Ártatlan Áldozatok Szatmári Svábok A Gulágon, Kiadó: Ludescher Gabriella, 244 oldal, ISBN 978-963-12-8166-8
} 
Amint a tanulmányok végén feltüntetett bibliográfiák bizonyítják, a szatmári svábok deportálásáról korábban is készültek kutatások, melyek publikálásra is kerültek. Ezek müfajukat tekintve visszaemlékezések, naplók, tanulmány-esszék, szépirodalmi alkotások. Kalandos történetek formájában mutatják be a szovjet munkatáborban zajló olykor-olykor megdöbbentően drasztikus eseményeket. Az eddigi kutatások közös jellemzöje, hogy központi témájuk a gulágon eltöltött idő, és a körülmények részletes bemutatása. Azzal, hogy a szerkesztő nem csak a gulág időszakát mutatja be, hanem az azt követő éveket is, - valamint az itthon maradottak nehézkes életkörülményeit -, e tekintetben jelen könyv hiánypótlónak minösül, hiszen korábban ilyen átfogó tanulmány nem készült.

A kötet szerkezetét tekintve több részből áll. Az első két rész, melyet Boros Ernő és Baumgartner Bernadette munkája, a deportálás kivitelezéséhez vezető utakat írják körül úgy, hogy az olvasót részletesen végigvezeti a történelem viharosabb eseményein. Az első világháborútól kezdi a történeti visszatekintést, majd azt az utat próbálja felvázolni, ami elvezetett ahhoz az úthoz, mely során a második világháború végeztével, a szatmári svábok deportálásához vezetett. A könyv első rész egyértelmüsíti és alátámasztja azt, hogy a hitleri Németország büneit a szatmári sváboknak kellett viselniük. Annak ellenére tették ezt, hogy önmagukat magyarnak tartották, magyarul beszéltek.

A szerkesztő az egész mủ során arra a kérdésre keresi a választ, hogy miért a sváb származású németül nem beszélő személyeket gyüjtötték össze, annak ellenére, hogy a szovjetek elsősorban a németeket tették felelőssé Oroszország háborús sérelmeiért. A feltett kérdésre a választ gyorsan megkapjuk, amikor is az Észak-Erdély históriáját részletező rész bemutatja a helyben élők származását, valamint a román fél deportálási érdekeltségeit. Erre a megállapításra Boros Ernő 1998-2002 közötti kutatómunkája nagyban hozzájárult, amikor is felkereste a szatmári sváb településeket és a történések eseményeiről kérdezte őket.

A deportálandók befogását településenként leírja, ami közelebb hozza az olvasót a történtek átéléséhez. Leírja, hogyan csapták be a lakosokat, milyen történeteket mondtak nekik, annak érdekében, hogy a deportálási folyamat zökkenőmentesen menjen végbe. A deportálások menetét is részletezi illetve azt is, hogy egyes falvakból miért deportáltak csak magyar svábokat, másokból pedig románok is kerültek az összegyüjtöttek közé. A könyv ezen része nagyon érdekes tényekre világít rá, melyek igazolását statisztikai adatokkal és interjúkkal támasztja alá. A tanulmány számos táblázatot tartalmaz, ami megkönnyíti a deportálási folyamat áttekintését és részleteiben mutatja be az egyes települések deportálási históriáját. A történeteket személyessé teszi, hogy név szerint említi az áldozatokat, mellyel egyben méltóképpen emlékezik meg a deportáltakról, és azok családtagjairól. A névsorok feldolgozásának módszere aprólékos, így megbízható adatokra építkezhetünk a felvezetö rész után. 
A könyv itt tárgyalt része a sikertelen és erőszakolt újranémetesítésről szól, konkrétan arról, hogy honnan és hogyan deportálták az áldozatokat. A deportálandók begyüjtésének módszerén túl, a tárgyalt rész egyik legnagyobb előnye az áttekinthetőség, és a személy közeli bemutatás. Az elszállásolási nehézségeknél részben a körülmények részletezésére kerül sor, így az élelmezés napi rutinjait egyéni sorsok mentén tárja az olvasó elé. A lágerélet és a munkaviszonyok leírása teszi a könyvet az olvasó számára megfoghatóvá. Az interjúk által a munkakörülmények drámai nehézségeit mutatja be. A mü egyik legtragikusabb része pedig a halálról szól. A deportáltak kártérítéséről írt résznél az érintett 4 ország kárpótlási mechanizmusait járja körül.

Baumgartner Bernadette: A szatmári svábok a népszámlálások tükrében címü részt olvashatjuk, mely egy fejezetrészlet a „Kisebbség a kisebbségben. A Szatmár megyei németek a két világháború között 1918-1940" címü könyvéből. A könyvnek ebben a részében történelmi felvezetéssel mutatja be a szatmári térséget és az ott élő svábok társadalmi beágyazódottságát. A számadatok tükrében elemzi a térség lakosainak nemzetiségi hovatartozását, népszámlálási adatokra alapozva. Az anyanyelv meghatározásával próbálták az 1880-as, 1910-es magyar, majd 1930-as román és az 1941-es magyar népszámlálási adatokból meghatározni a svábok arányát a vizsgált településeken. A könyv itt elemezett részének legnagyobb pozitívuma, hogy figyelembe veszi az adott politikai közeget, ami az adatok megbízhatóságára is hatással volt.

A könyv következő meghatározó fejezete a Fényi József által írt: Kényszermunkán a Szovjetunióban címü rész. Terjedelmében a leghosszabb fejezet, melyben egyéni életúton keresztül írja le - a legapróbb részletekig - a deportálásának történetét. A szerző nagybányai lakos, aki az 1970-es években, 18 különálló részből álló írásában átfogó áttekintést próbál adni a történésekről. Bemutatja a helyi közösséget ahonnan elszállították, a deportálás napját, illetve részletezi az általa átélt negatív élményeket. A vonatúttól kezdve taglalja a deportáltak életvitelét, a lágeréletet és az elszállásolás körülményeit, egészen a hazaérkezéséig. Bár a szerző a lágerélet eseményeit meséli el, a fejezet legfőbb mondanivalója - amellett, hogy bemutatja a munkatábor körülményeit - az emberi viszonyok bemutatása, melyek a különböző szükséghelyzetekben testet öltenek. A közel 5 év eseményeit évenként lebontva elemzi, és havi lebontásban kapunk képet Fényi József lágerben töltött éveiről.

A terjedelmes részt Ludeser Viktor naplóképeiböl álló összefoglaló követi, majd Ludescher Gabriella (szerkesztő): Hittel telített levelek címü írását olvashatjuk. A keresztény hit erősségéről tesz tanúbizonyságot a szerző azzal, hogy bemutatja az elhurcoltak és az otthonmaradottak Istenbe vetett hitét. Megemlékezik Scheffler János püspök cselekedeteiröl, aki a deportáltak érdekeit önfeláldozó módón képviselte. A püspök élesen fellép a deportálások ellen, ezzel közbenjárva hívei érdekében. 
Az ezt követő fejezet Ludescher Gabriella: Társadalmi trauma címet viseli. Ezen rész ismeretlen szerző versével kezdődik, és az otthonmaradottak szemszögéből mutatja be a deportálások hatásait. A társadalmi változásokat és azok jellemzőit írja le a szerző. A következő lényegesebb részben, mely a gazdasági és a hatalmi kórlépről íródott, a megélhetési nehézségeket írja le Heninger István naplója segítségével, mely Boros Ernő gyüjtése során került birtokába. Az élelmiszerek pontos árának bemutatásával kristálytiszta képet kapunk az akkori gazdasági folyamatokról. A napló napra pontosan jegyzi az eseményeket, majdnem 5 év időtartamát átölelve. Valódi társadalmi életképet kapunk az akkori gazdasági helyzetről. A társadalmi trauma abban is megnyilvánul, hogy a deportálásból hazaérkezők a kommunizmus további elszenvedői voltak a beszolgáltatások által. Az identitás kórképnél részletezi a szerkesztő, hogy a nyelvi és etnikai hovatartozás érzése miként figyelhető meg a deportáltak esetében. Az Egy fiatal lány-kórképénél a szexuális visszaélések olvashatóak.

A könyv vége felé haladva fotók ábrázolják a kor embereit. A lágerlakókról készült képeket a kommunista propaganda engedélyezte hazaküldeni, amely képek előnyösen mutatták be az ott dolgozó kényszermunkásokat. A kötet végéhez érve a szerkesztő az interjúzás tapasztalatairól ír, és összegzi a korszak történéseit. Az emlékezés fontosságát hangsúlyozza, melyhez e könyv megjelenése lényegesen hozzájárul. A könyv utolsó részében a deportáltak hosszú névsorát olvashatjuk, településenként tagolva.

A könyv által vizsgált probléma elsőszámú jelentősége az, hogy felhívja a figyelmet a történelem eme sötét időszakára, amikor is olyan embereknek kellett a nagyhatalmak csatározásait és bosszúit megszenvednie, akik önmaguk nem tehettek róla. A történések emberközeli megismerése egyértelmüsíti azt is, hogy ezen igazságtalanság elszenvedői kárpótlást mai napig csak részben vagy egyáltalán nem kaptak. A felhasznált elemzési technikák, a tudományos módszerek, a pontosság, és a precíz elemzési technikák alapozzák meg a könyv értékét. A kutatott történelmi jelenséggel egy fontos probléma feltárását és megválaszolását tárja az olvasók elé. A felhasznált és alkalmazott módszerek, források és adatok használatára jellemző az objektivitás, és a kutatói munka alapossága. A kutatás elméleti része a hazai szakirodalomban megjelent tanulmányok széles körét felhasználta. Az eredmények a további kutatások során felhasználhatóak. A könyv az ifjúság számára tankönyvként is alkalmazható, mivel a száraz tények helyett emberi oldalról teszi megfoghatóvá és figyelemfelkeltővé a szerkesztett könyvet.

A kötet stílusa szinergiában van a könyv témájával és céljával egyaránt. A könyvben található táblázatok, fényképek, illusztrációk figyelemfelkeltőek, és bemutatják azokat a jelentős eseményeket, amelyekre a könyv szerkesztője felszerette volna hívni a figyelmet. Összességében a könyv olvasását jó szívvel ajánlom mindenkinek, aki a történelem eseményeiből tanulni szeretne, és emlékezni azokra, 
akiknek az életét korábban megkérdőjelezhetetlennek titulált ideológiák megkeserítették, vagy teljes egészében elvették.

\section{Virág Ádám}

A Debreceni Egyetem Egészségügyi Karán szerzett szociális munkás diplomát, majd okleveles szociális gazdasági szakember végzettséget. 2017-ben az Országos Tudományos Diákköri Konferencián első helyezést ért el, majd ezt követően a Magyar Tudományos Akadémián Pro Scientia Aranyéremmel tüntettek ki. 